\title{
DETERMINATION OF THE SPECIFIC GROWTH RATE ON DEGRADATION OF CASSAVA SEWAGE USING MICHAELIS-MENTEN EQUATION
}

\author{
I. M. Jideofor* \\ Dept Of Civil Engineering, Michael OKPARA University of Agriculture, UmUdike, ABia State, NiGERIA. \\ E-mail address. ifymgj@yahoo.com
}

\begin{abstract}
Sewage generation is one of the dense problems Nigerians encounter on daily bases, mostly at the urbanized area where factories and industries are located. This paper is aimed at determining the specific growth rate " $K$ " of biological activities on cassava wastewater during degradation using Michaelis-Menten Equation. In order to achieve this, cassava wastewater were collected from Onuiyi cassava processing plant at Nsukka urban area after fermentation. The wastewater was tested and analyzed in Civil Engineering Sanitary Laboratory UNN, Nsukka. An aerobic technique was used to effect the degradation in a batch reactor. Sodium hydroxide (NaOH) was used to oxidize the inhibitor (cyanide) and the results were modeled using Michaelis-Menten equation. Statistical regression analysis was adopted for the calculation of the $k$-value using the line-weaver burk plot for MichaelisMenten equation. The result showed higher $K$-value of 0.7149 at $6 \mathrm{~g}$ of $\mathrm{NaOH}$ resulting in optimum degradation over other concentrations. The substrate concentration is higher at $10 \mathrm{~g}$ and low at $0 \mathrm{~g}$ and $2 \mathrm{~g}$. At higher concentration of the $10 \mathrm{~g}$ of $\mathrm{NaOH}$ the inhibitor was less successful in competing with the substrate optimizing to lower inhibition degree. The model enables us to understand the inhibitor content and the degree of degradation of cassava waste water. There is need for further study on this model, to examine the inhibition factors in cassava waste water degradation.
\end{abstract}

Keywords: cassava, specific growth rate, sewage, fermentation, batch reactor

\section{INTRODUCTION}

Manioc (Manihot Esculentz) or "Yucca" tapioca typically known as cassava is one of the root crops grown in many countries, such as tropical Africa, Asia and South Africa where it is grown largely. [1], [2], [3] recorded that in Sub-Saharan African (SSA) cassava is currently the major staple food for $40 \%$ of the population and for a estimated 500 million people in the tropics. It is partially substituted for wheat flour in Africa, thus providing income for resource poor farmers and saving foreign exchange for national government. Some people also eat the leaves of cassava as a green vegetable which provide cheap and rich source of protein and vitamins A and B [4]. Its fermentation is a popular process in the whole world, for food and animal feeds. It is the main source of carbohydrate in the diet of the teeming population of the world countries where it grown largely [5]. Wastewater from cassava starch industry usually is a result of the cassava root washing and the starch extraction activities [6]. According to [5], cassava is the most widely distributed major food crop with a high content of cyanogenic glycosides. The content of cyanide in cassava is in form of glycoside, that is, linamarin (93\%) and lotaustralin (7\%). There is general agreement that overestimate the actual cyanide toxicity to aquatic organisms and the analytically determination of hydrocyanide ( $\mathrm{HCN}$ ) concentration in cyanide polluted waters, is considered to be the most reliable index of toxicity [7]. Therefore, the observed toxicity to aquatic life of simple and complex cyanide was attributed almost entirely to molecular (undissociated) hydrocyanide acid (HCN) derived from ionization, dissociation and photodecomposition of cyanide containing compounds. Hydrocyanide acid (HCN) is easily liberated from cassava cyanide glycosides by the enzyme linamerase in which case plant cells are physically disrupted. However, the ingestion of high

* Corresponding author, tel: +234-803-955-6246 
concentration of cyanogenic glycosides from fresh cassava roots and leaves has been reported to be lethal in numerous species of animals. This was because the possibility of hydrolysis during digestion was not adequately understood, despite early reports that oral doses of pure linamanin produced physiological and biochemical changes in rats and chick embryos even in the absence of linamarase. Cyanide in cassava root crop can be eliminated or reduced through some concerted efforts. These efforts include sun drying, oven drying, and treatment with chemical preparation, steeping /retting or soaking in water, cooking and wetting/moistening [8]. All these efforts are with varied levels of success, cost effectiveness and adaptability to local technologies. Fermentation either naturally or with selected microbial inoculums has also been extensively used to enhance the nutrient potentials of cassava and its byproducts both for human and livestock consumption. Fermentation, boiling and ensiling are efficient techniques for removing the constraint from cassava [9]. Fermentation of cassava and its by-products automatically qualifies such products as fermented foodstuffs. According to [10], the fermented foodstuffs are defined as animal or plant tissues subjected to the action of micro-organisms and/enzymes to give desirable biochemical changes and significant modification of food quality. The need for fermentation was outlined by [11],

- Detoxification of food/feed anti-nutrients during the process of fermentation.

- Biological enrichment of food substrates with proteins, essential amino acids, essential fatty acids and vitamins.

- Enrichment of the fermented products through the impartation of an array of aroma flavours and textures.

- Preservation of the fermented products through the production of lactic acid, acetic acid, alcohol and alkali in the substrate as a result of fermentation.

- Decrease in cooking time and fuel requirements.

The outlined reasons have been achieved through fermentation of cassava and cassava by-products. Cassava and its by-products fermentation is popularly achieved in two-way techniques known as liquid substrate fermentation and solid substrate fermentation. The liquid substrate fermentation is described as the one in which water is always in a free state while food nutrients in the form of carbon, nitrogen, phosphorus and others are in a suspended or dissolved state. In regard to this technique, there is an order to ensure a successful fermentation in which the strict observance of aseptic inoculation of microorganisms which could only be economically feasible when done on an industrial scale, i.e., its application is yet to be suited to the traditional village setting where the bulk of the producers of cassava and its products are domiciled. Apart from the requirement of a sterile environment for the operation of submerged fermentation, enzymatic or acid treatment of starch is necessary when yeasts are to be used as the microbial inoculums. The recovery of the cell mass could be tedious and might involve further processes like centrifugation/ultra-filtration before separation of cell biomass could be achieved [12]. While the solid substrate fermentation is a biosystem consisting of a solid, porous, water absorbing matrix, which can either be biodegradable or not of relatively high water activity on solid/gas interface in which air mixture of oxygen with other gases freely circulate under a relatively low pressure within the fermenting substrate [13]

\section{MATERIAL AND METHOD}

\subsection{Samples and Sampling Techniques}

The cassava wastewater samples were gotten from a cassava processing plant located at Nsukka $\left(6.86^{\circ} \mathrm{N}\right.$ and $\left.7.4^{\circ} \mathrm{E}\right)$, Enugu state South Eastern Nigeria. The waste water generated from fermentation of the cassava for 4 days were sifted with a plastic sieve and collected in 50 litres plastic container and then transported to the Sanitary engineering laboratory of Civil Engineering Department of the University of Nigeria Nsukka for laboratory tests. An aerobic technique was adopted for the batch reactor using six different plastic buckets of (2.0 litres capacity. The buckets were properly identified and labeled $X_{1}, X_{2}, X_{3}$, $X_{4}, X_{5}$, and $X_{6}$. Sample $X_{1}$, is for the control experiment, and the order samples from $X_{2}$ to $X_{6}$ were diluted with sodium hydroxide in neighborhood of $2 \mathrm{~g}, 4 \mathrm{~g}, 6 \mathrm{~g}, 8 \mathrm{~g}$, and $10 \mathrm{~g}$ respectively. The set up were stored for 20 days. After 20 days, the values for the monod constants $\mathrm{y}, \mathrm{Kd}, \mathrm{K}_{\mathrm{O}}$ and $\mathrm{K}_{\mathrm{m}}$ were recorded and analyzed.

\subsection{Mathematical Derivations}

Under steady state conditions, mass balance is written differently for substrate and biomass using Monod kinetic model. The rate of formation of biomass or utilization substrate can be assumed. Therefore, from steady state completely mixed Monod reactor 
Accumulation $=$ inflow - outflow + decay

Mathematically written as

$$
\frac{V d c}{d t} \cdot=\mathrm{Q} c \mathrm{o}-\mathrm{Q} \mathrm{c}+\mathrm{V}(-\mathrm{Kc})
$$

Where $\mathrm{V}$ is the volume of reactor, $\mathrm{c}_{0}$ and $\mathrm{c}$ are the influent and effluent waste concentration respectively, $\mathrm{Q}$ is the flow rate and $\mathrm{k}$ is the reaction coefficient.

Assume a steady state $\frac{V d c}{d t}=0$, then equ (1) becomes

$$
0=\mathrm{Qc}_{0}-\mathrm{Qc}-\mathrm{VKc}
$$

From Monod model $[14,15]$,

$$
\mathrm{K}=\frac{K_{0} X}{Y\left(K_{m}+S\right)}
$$

Substituting for $\mathrm{K}$ in equation (2)

$$
\begin{aligned}
& \text { Qso- Qs }-\frac{K_{0} S X V}{Y\left(K_{m}+S\right)}=0 \\
& \text { Qxo- Qx }-\frac{K_{0} S X V}{K_{m}+S} \cdot+\mathrm{KdXV}=0
\end{aligned}
$$

But Xo $=0$

Then:

$$
-\mathrm{Qx}-\frac{K_{0} S X V}{K_{m}+S}+\mathrm{KdXV}=0
$$

In the above equations $\mathrm{s}$ and $\mathrm{x}$ are the substrate and biomass respectively, $\mathrm{k}_{0}$ is maximum specific growth rate, $k_{d}$ is the death rate, $k_{m}$ substrate saturation constant, and y is the growth yield.

Therefore, divide right through by XYQ, to obtain

$$
-\frac{1}{Y}-\frac{K_{0} S V}{Y Q\left(K_{m}+S\right)} \frac{\mathrm{K}_{\mathrm{d}} V}{Y Q}=0
$$

but $\mathrm{V} / \mathrm{Q}=\theta$

where $\theta$ is the detention time

$$
\frac{K_{0} S \Theta}{Y\left(K_{m}+S\right)}=\frac{\mathrm{K}_{\mathrm{d}} \Theta}{Y}+\frac{1}{Y}
$$

But from equation (4)

$$
\begin{aligned}
& \frac{S o-S}{X}=\frac{K_{0} S \theta}{Y\left(K_{m}+S\right)} \\
& \quad \frac{S o-S}{X}=\frac{\mathrm{K}_{\mathrm{d}} \Theta}{Y}+\frac{1}{Y}
\end{aligned}
$$

By inversion of equation (10)

$$
\frac{X}{S o-S}=\frac{Y}{K d \theta}+\mathrm{Y}
$$

Since $\frac{S o-S}{X}=\frac{K_{0} S \theta}{Y\left(K_{m}+S\right)}$

Then

$$
\frac{X}{S o-S}=\frac{Y\left(K_{m}+S\right)}{K_{0} S \theta}
$$

Simplifying equation (9) further, it becomes

$$
\frac{X \theta}{S o-S}=\frac{Y K_{m}}{K_{0}} 1 / S+\frac{Y}{K_{0}}
$$

Where $\mathrm{K}_{\mathrm{d}}, \mathrm{Y}, K_{m}$, and $\mathrm{K}_{\mathrm{o}}$ are constants, and can be determined graphically or by regression analysis. From the equations (10) and (13); $1 / \mathrm{Y}, \mathrm{Y} / \mathrm{K}_{0}$ and $\mathrm{K}_{\mathrm{d}} / \mathrm{Y}, \mathrm{Y} K_{m} / \mathrm{K}_{\mathrm{o}}$ is the intercepts and slopes of the both equations.
Furthermore, dividing equation (13) by $\mathrm{Y}$, gives

$$
\frac{X \theta}{(S o-S) Y}=\frac{K_{m}}{K_{0}} \times \frac{1}{S}+\frac{1}{K_{0}}
$$

But from equation (12)

Therefore from [14 - 16],

$$
\frac{1}{K}=\frac{K_{m}}{K_{0}} \times \frac{1}{S}+\frac{1}{K_{0}}
$$

Presenting equation (15) in a graphical method shows the Typical Line weaver-Burk plot for the MichaelisMenten equation which was called uninhibited inhibition, where $K_{m} / K_{0}$ and $1 / K_{0}$ are the slope and intercept respectively.

\section{RESULTS AND DISCUSSIONS}

The use of the equations $\frac{S o-S}{X}=\frac{\mathrm{K}_{\mathrm{d}} \Theta}{Y}+$ $\frac{1}{Y}$ and $\frac{X \theta}{S o-S}=\frac{Y K_{m}}{K_{0}} 1 / S+\frac{Y}{K_{0}} \quad$ obtained from the steady state equation was regressed analytically to achieve the growth yield " $\mathrm{Y}$ ", death rate " $\mathrm{K}_{\mathrm{d}}$ ", maximum Specific growth rate constant " $\mathrm{K}_{0}$ " and Michealis-Menten constant " $\mathrm{K}_{\mathrm{m}}$ " which enable the achievement of the Specific growth rate result "K" of biological activities in the reactors. This was achieved for different concentrations of the addition of sodium hydroxide and tabulated in Table 1 below. The specific rate growth depends on the line weaver burk equation which relatively deduced the biomass concentration and microbial growth that depends on the substrate concentration.

From equation (10)

Let $\mathrm{y}=\frac{S o-S}{X},, \mathrm{a}=\frac{\mathrm{K}_{\mathrm{d}}}{Y}, \mathrm{~b}=\frac{1}{Y}$, and $\mathrm{x}=\mathrm{\theta}$,

By regressing " $y$ " on " $\mathrm{x}$ ", we obtain " $a$ "

Note that, $\bar{y}=a \bar{x}+b$

But $\frac{1}{Y}=\mathrm{b}=\bar{y}-a \bar{x}$

From equation (13)

$\mathrm{Y}=\frac{X \theta}{S o-S} ., \mathrm{a}=\frac{Y K_{m}}{K_{0}}, x=\frac{1}{S}, \mathrm{~b}=\frac{Y}{K_{0}}$,

Regressing "y" on " $x$ " we obtain "a"

Then, $\bar{y}=a \bar{x}+b$

$\mathrm{b}=\bar{y}-a \bar{x}$

$$
\frac{Y}{K_{0}}=\overline{\frac{X \theta}{S o-S}}-\frac{Y K_{m}}{K_{0}} \frac{\overline{1}}{S}
$$

\subsection{Determination of the $\mathrm{K}$ value (specific growth rate)} Equation (15) was used for the presentation of graph to determine the slopes and intercepts which enables the determination of $\mathrm{k}$ values mathematically for different grams of $\mathrm{NaOH}$ added. The coefficient correlation value ( $r$ ) shows the bacterial growth fitness in the experiment. 
Table 1. The Monod constant values at different concentrations of sodium hydroxide

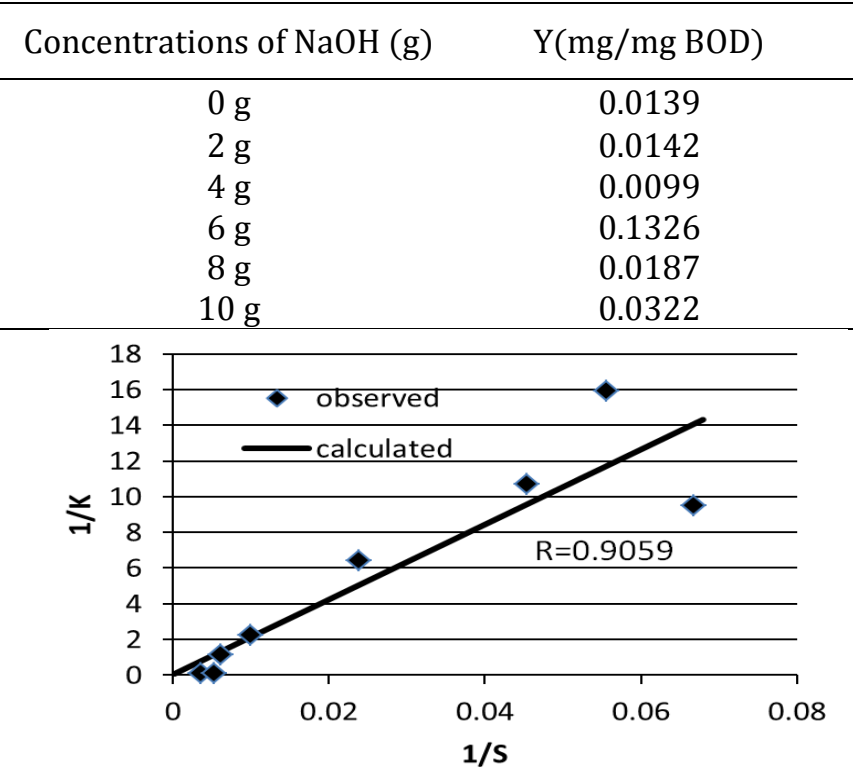

Fig.1: Variation of $1 / K$ with $1 / S$ for the calculated specific growth rate at $\mathrm{O} g$ of $\mathrm{NaOH}$

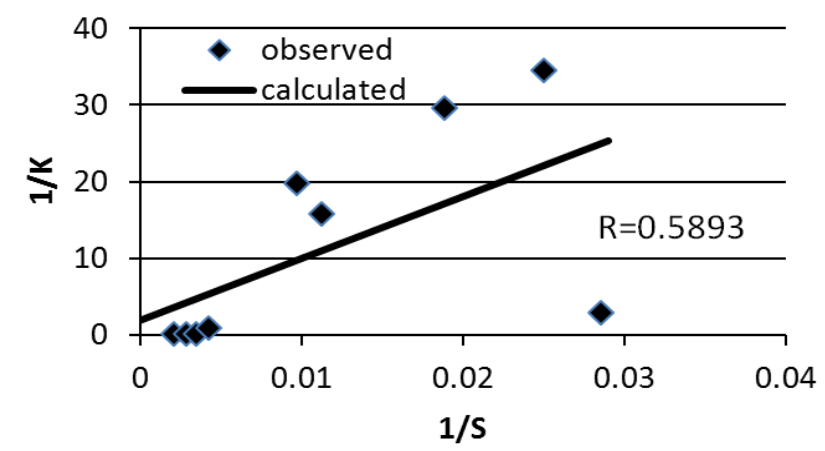

Fig. 3: Variation of $1 / K$ with $1 / S$ for the calculated specific growth rate at $4 \mathrm{~g}$ of $\mathrm{NaOH}$

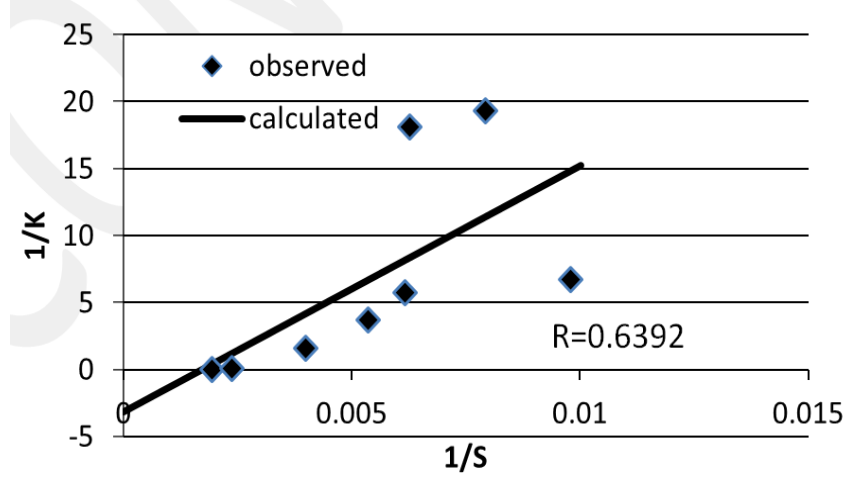

Fig. 5: Variation of $1 / K$ with $1 / S$ for the calculated specific growth rate at $8 \mathrm{~g}$ of $\mathrm{NaOH}$

The cassava wastewater was observed to be highly acidic at $0 \mathrm{~g}$ and highly alkaline at $10 \mathrm{~g}$. The observation, indicate unsafe disposal of untreated cassava sewage to the environment or rivers at these concentrations. The determination of the specific growth rate $\mathrm{K}$, varies with the concentration reaction of the oxidizing agent added to reduce the inhibitor (cyanide content) for easy degradation over time. At 6

$\begin{array}{ccc}\mathrm{K}_{\mathrm{d}} \text { (day) } & \mathrm{K}_{0} \text { (day) } & \mathrm{K}_{\mathrm{m}}(\mathrm{mg} / \mathrm{l}) \\ 0.0164 & 2(2.0635 & 5604.9206 \\ 0.0359 & 0.0915 & 30.4859 \\ 0.0907 & 0.5156 & 416.40 \\ 0.6463 & 6.8 & 724.5897 \\ 0.0489 & 0.3159 & -0.57 \\ 0.1104 & -0.4435 & -611.7989\end{array}$

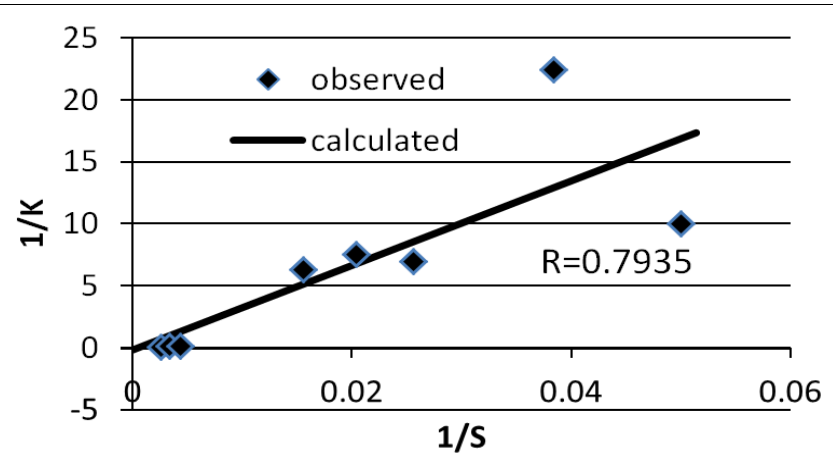

Fig. 2: Variation of $1 / K$ with $1 / S$ for the calculated specific

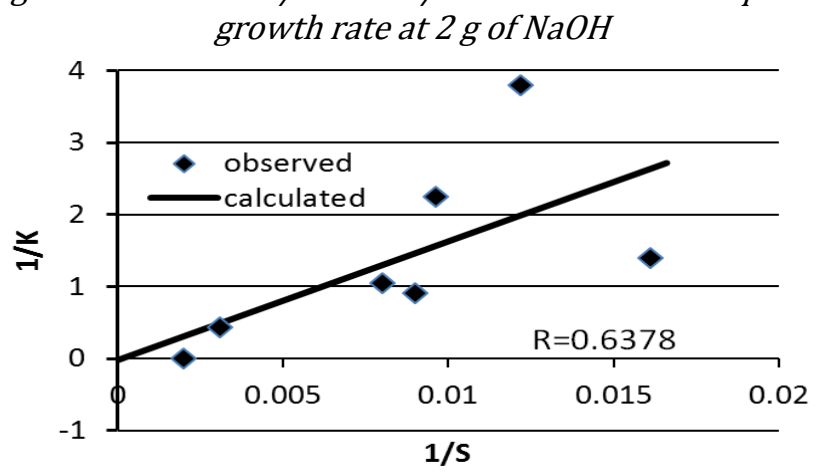

Fig. 4: Variation of $1 / K$ with $1 / S$ for the calculated specific growth rate at $6 \mathrm{~g}$ of $\mathrm{NaOH}$

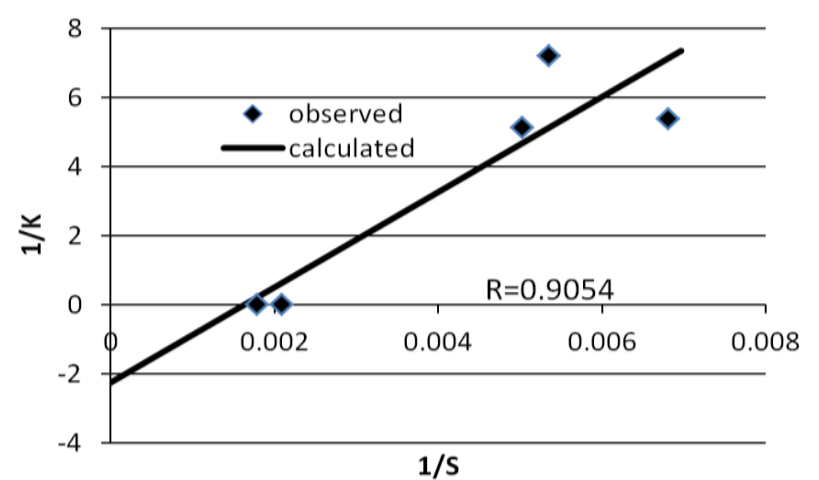

Fig. 6: Variation of $1 / K$ with $1 / S$ for the calculated specific growth rate at $10 \mathrm{~g}$ of $\mathrm{NaOH}$

$\mathrm{g}$ additive of sodium hydroxide, $\mathrm{K}$ is 0.7149 higher than others. This could be as a result of the inhibitor (cyanide) combining with the enzyme molecules not minding if the substrate molecule bound or not. Therefore it produces an ideal end complex enzyme in the reactor indicating non-competitive inhibition. Because $Y, K_{d}, K_{0}$, and $K_{m}$ are result higher at the sixth gram addition of sodium hydroxide. It shows that 
degradation was more efficient as the substrate consumption was highly represented at the growth rate of $0.1326 \mathrm{mg} / \mathrm{mg}$ BOD in Table 1 . The death rate predation by higher organisms are lumped together and accounted for growth of the microorganisms, which accompanied by secretion of substance into the reactor and result into enzyme inhibition. These substances will have an inhibitory effect on the growth of the microorganisms, which could be competitive or non-competitive. The enzyme inhibition effect is minimal in the continuous flow tank system.

\section{CONCLUSION}

Result indicates that the substrate concentration is lower at $0 \mathrm{~g}$ and $2 \mathrm{~g}$ of the reagent identifying higher degree of inhibition for the fact that the inhibitor compete favorably with the substrate. At the higher degree substrate concentration observed at $10 \mathrm{~g}$, the inhibitor becomes much less successful in competing with the substrate optimizing to a lower inhibition degree.

Statistical regression analysis help in effective and efficiency of calculating the specific growth rate using the line-weaver bulk plot for the Michaelis-Menten equation which was obtained from the steady state completely mixed monod reactor. It enables the observation of inhibitor in a wastewater and the type of inhibition involved. Cassava effluents which are one of the sewage samples are toxic and harmful to the ecological system, though it causes nuisance to the environment. The toxic substance observed causes this effluent inhibits its degradation. The model enables us to understand the inhibitor content and the degree of degradation of cassava waste water. There is need for further study on this model, to examine the inhibition factors in cassava waste water degradation.

\section{REFERENCES}

[1] Dufour, D. L.. Effectiveness of Cassava Detoxification Techniques Used by Indigenous People in the Northwest Amaonnic. Interciencia 14(2) 86-91, 1989.

[2] Okafor P. N.. Assessment of cyanide overload in cassava consuming populations of Nigeria and the cyanide content of some cassava based foods. African Journal of Biotechnology 3(7)358-361, 2004.

[3] Burns A., Gleadow, R., Cliff, J., Zacarias, A. and Cavagnaro T. Cassava: the drought, war and famine crop in a changing world. Sustainability 2(11)35723607, 2010.

[4] Okunde, D. A and Adekalu K. O. Physico-Chemical Analysis of Contaminated Water Resources Due to Cassava Wastewater Effluent Disposal. European international journal of science and technology, Vol 2 No 6, pp 75-84, 2013.

[5] Jideofor I. M., Agunwamba J. C.. Analysis of Inhibition of Cassava Wastewater by Cyanide. Journal of Engineering and Applied Sciences, Vol. 7 No 1\&2, 2011 pp 80 -87, 2011.

[6] Cereda M. P.. Caracterizacao dos sibprodutos da industrializacao da mandioca. In: manejo, uso $e$ tratamemto de subprodutos da industrializaco da mandioca SP: Fundacao Cargill p.13-37, 2001.

[7] Irwin, J.,. Environmental Contaminants. Encyclopedia Entry on Cyanide(s) in General Pg 7-64, 1997.

[8] Batstone, D. J., Keller, J., Angelidaki, R. I., Kalyuzhnyi, S. V., Pavlostathis, S. G., Rozzi, A., Sanders, W.T.M., Cuzin, N. and Labat, M.. Reduction of Cyanide Levels during Anaerobic Digestion of Cassava. International Journal of Food Science and Technology, 27, 329 336, 1992.

[9] Padmaja, G., and Steinkraus, K.H.,. Critical Review in Food Science and Nutrition. Vol. 3.5 Comell University New York.299-339, 1995.

[10] Campbell-Platt, G.. Fermented Foods - a World Perspective. Food Res. Int. 27: 253., 1994.

[11] Steinkraus, K. H.,. Handbook of Indigenous Fermented Foods. New York, Marcel Dekker, Inc., 776., 1995.

[12] Balagopalan, C., Padmaja, G., George, M.. Improving the Nutritional Value of Cassava Products Using Microbial Techniques. FAO-Corporate Document Repository, Anim. Prod. Health Paper95-2002.

[13] Raimbault, M.. General and Microbiological Aspects of Solid Substrate Fermentation, Elect. J. Biotechnology, Vol. 1 No. 3., 1998.

[14] Roger, A., and Gibon, Y.,. Enzyme Kinetics Theory and Practice Department of Environmental Sciences, Brookhaven National Laboratory Upton, NY119735000, USA. Email: arogers @bral.gov.pp 1-33, 2009.

[15] Palmer, T. B.A.,. Understanding Enzymes, $2^{\text {nd }}$ edition, Ellis Harwood Publication New York. Pp 150-172, 1985

[16] Agunwamba, J.C.. Waste Engineering and Management Tools, Immaculate Publication Ltd, Enugu. 153-179, 2011.

Table 2: The " $k$ - values" for different gram of the reagents

\begin{tabular}{ccccccc}
\hline & $0 \mathrm{~g}$ & $2 \mathrm{~g}$ & $4 \mathrm{~g}$ & $6 \mathrm{~g}$ & $8 \mathrm{~g}$ & $10 \mathrm{~g}$ \\
\hline $\mathrm{S}(\mathrm{mg} / \mathrm{L}$ BOD $)$ & 36.9276 & 55.8659 & 84.7458 & 116.2791 & 181.8182 & 238.0952 \\
$\mathrm{~K}($ day $)$ & 0.1444 & 0.1651 & 0.0872 & 0.7149 & 0.1022 & 0.1869 \\
$\mathrm{R}$ & 0.9059 & 0.7935 & 0.5893 & 0.6378 & 0.6392 & 0.9054 \\
\hline
\end{tabular}

